\title{
Philosophiques
}

\section{L'immutabilité du Dieu biblique et du Deus Thomisticus (Réponse à B. Garceau)}

\section{John King-Farlow}

Volume 3, numéro 2, octobre 1976

URI : https://id.erudit.org/iderudit/203058ar

DOI : https://doi.org/10.7202/203058ar

Aller au sommaire du numéro

Éditeur(s)

Société de philosophie du Québec

ISSN

0316-2923 (imprimé)

1492-1391 (numérique)

Découvrir la revue

Citer ce document

King-Farlow, J. (1976). L'immutabilité du Dieu biblique et du Deus Thomisticus (Réponse à B. Garceau). Philosophiques, 3(2), 285-288.

https://doi.org/10.7202/203058ar d'utilisation que vous pouvez consulter en ligne.

https://apropos.erudit.org/fr/usagers/politique-dutilisation/ 


\section{Bulletin}

\section{L'IMMUTABILITE DU DIEU BIBLIQUE ET DU DEUS THOMISTICUS}

(Réponse à B. Garceau)

par John King-Farlow

Le bulletin La philosophie analytique de la religion: Contribution canadienne 1970-1975, publié dans la revue Philosobiques [II,2, 1975, 301-339], mérite l'expression d'une vive reconnaissance non seulement dans plusieurs camps analytiques mais aussi à l'intérieur de chaque temple dédié à la critique du théisme. Par conséquent, nous prenons le risque d'apparaître coupable d'une ingratitude extraordinaire à l'égard de $M$. Benoît Garceau, en élevant quelque protestation contre ses commentaires si méticuleux. Néanmoins, en nous inspirant d'un adage favori d'Oscar Wilde, "Je sais résister à toute chose - à l'exception de la tentation elle-même ", nous nous occuperons de deux citations, où $M$. Garceau se fourvoie, peut-être, d'une manière instructive :

(I) "Ce qui étonne dans ce genre d'analyse de la religion, c'est avant tout le fait qu'elle contribue si peu à comprendre le christianisme, la seule religion habituellement étudiée par les analystes. " [P. 338 - ici M. Garceau excuse seulement M. Fackenheim, qui s'oppose à la tradition analytique.]

(II) "Soutenir en tout cas que le concept d'un dieu immuable et intemporel chez Thomas d'Aquin lui est venu de son attachement à Aristote et n'a rien à faire avec le message biblique (pp. 112 ss) me paraît traduire un manque évident de sens de l'histoire. La théologie augustinienne, par exemple, que personne ne saurait soupçonner de lien avec l'aristotélisme, accordait pourtant à l'immutabilité de Dieu le rôle de premier des attribus de Dieu. " [P. 337. Ici, M. Garceau évalue notre livre Faith and the Life of Reason].

Ces textes, nous semble-t-il, manifestent une désorganisation intellectuelle, qui n'est pas du tout représentative de ce bulletin. 
Mais ils servent à révéler une question bien digne des discussions entre les thomistes, les phénoménologues de la religion, les analystes anglosaxons et les historiens de la pensée biblique. Il nous suffit de présenter quelques petites observations et d'y ajouter deux citations qui sont prises (a) d'un penseur suprêmement analytique qui connaît bien la théologie chrétienne, (b) d'un théologien moderne qui sait utiliser les instruments de l'analyse logicolinguistique.

On s'embrouille dans l'inconséquence si l'on implique à la fois (i) que les analystes n'ont pas posé efficacement des problèmes qui augmentent notre compréhension du christianisme, mais (ii) que le concept d'un Dieu immuable, scruté vigoureusement par les analystes, appartient d'une façon essentielle aux traditions centrales du christianisme. Il se peut que cette inconséquence dérive $\mathrm{du}$ fait que trop de thomistes, qui sont autrement perspicaces, traduisent à l'égard de ce concept un manque évident de sens de l'histoire biblique. En outre, la phrase (I) de M. Garceau manifeste une ignorance des études analytiques consacrées depuis longtemps par M. Ninian Smart et M. David Bostow, inter alios, aux religions occidentales.

(I) Évidemment Aristote n'est pas le seul philosophe grec qui inspirait les penseurs chrétiens. Il n'est pas non plus le seul Grec pour lequel le concept d'un être qui est immuablement parfait devient celui d'un individu qui est complèment immuable et, ainsi, non pas temporel. À cette page 112, citée dans la première phrase de $(B)$, nous mentionnons que Platon et le néo-platonisme, et non seulement Aristote et ses commentateurs, influençaient Thomas d'Aquin. Le paradigme platonicien d'une idée, qui appartient au domaine atemporel d'EINAI, si supérieur au monde des GIGNOMENA, contribua profondement à la théologie augustinienne. Cependant, si saint Augustin s'intéressait plus à Platon et saint Thomas plus à Aristote, il ne s'ensuit pas que l'un fut plus fidèle que l'autre aux concepts bibliques du Dieu parfait. Il ne s'ensuit pas non plus que si saint Augustin fut plus fidèle à Platon, il fut également plus fidèle à ces concepts bibliques. Et ces concepts doivent contribuer beaucoup à notre compréhension de la religion biblique des juifs et des premiers chrétiens : leur Dieu ressemble bien plus à un père hébraïque et moins à une abstraction grecque, que la théologie thomiste ou augustinienne nous le représente. 
Notre inférence que l'immuabilité du bon Dieu chez Thomas d'Aquin dénature la notion acceptée par tant de prophètes bibliques et par Jésus de Nazareth n'est pas tirée simplement, comme suggère M. Garceau à ses lecteurs, de la prémisse que l'auteur de la Summa Theologica adorait Aristote comme le Philosophus philosophorum. Nous offrons dans ces pages citées [12 ss.] nos propres arguments. En outre, nous y considérons ceux de Boas et de Brightman. Ces sortes d'arguments indiquent la même direction qu'acceptent un nombre croissant de spécialistes modernes.

Voici deux exemples de ce genre sur lesquels on aurait profit à réfléchir

(EL) " Of course, if the doctrine of timelessness could be justified by reference to the basic concept of God . . . or if it could be supported by reference to biblical or confessional materials, then it might have to be retained in theology even if its systematic effect were largely that of chaos. But, again, there appears to be little reason to think that this doctrine is implied by the basic Christian concept of God (Ch. 8), nor have I been able to find any basis for it in Biblical literature, or in the confessional literature of the Catholic and Protestant Churches... In Vol. I., Ch. I of God: His Existence and His Nature .... R. Garigou-Lagrance affirms that God's eternity is to be understood as excluding duration. He points out, however, that this item is not a dogma of the Catholic faith ... It is now my suspicion that the doctrine of God's timelessness was introduced into Christian theology because Platonic thought was stylish at the time and because the doctrine appeared to have considerable advantage from the point of view of systematic elegance. " (Nelson Pike, God and Timessness; London, Routledge and Kegan Paul, 1970, pp. 189-190).

"The Lord, we are told [by Malachi, 3:5-7] persists in certain attitudes (devotion to Isræl), and in this constancy of basic attitude he changes not. But, so far from affirming or implying complete metaphysical immutability the passage seems rather to support the idea of divine change. 'Return to me and I will return to you' amounts to this : change in a certain direction, and I will myself change in a thereto appropriate way. The principle of appropriateness in unchanging, but neither the wordly objets of divine attention nor the divine responses thereto are depicted as 
immutable. " (Charles Hartshorne, Philosophers Speak of God; University of Chicago Press, Third Impression, 1965 ; p. 37).

Université de l'Alberta

Ceux qui aimeraient se procurer, à des conditions intéressantes, la collection de Dialogue de 1962 à 1972 inclusivement, peuvent s'adresser à Mme Madeleine Sauvé, Secrétariat général, Université de Montréal, B.P. 6128, Montréal, P.Q. H3C 3J7. Téléphone : 514-343-7818. 